\title{
POSTPARTUM WOMEN'S LEVEL OF COMPREHENSION OF NEWBORN CARE INSTRUCTIONS AT A ROOMING-IN FACILITY
}

\author{
Bruna Cabrera Dauber ${ }^{1}$, Maria Luzia Chollopetz da Cunha²
}

\begin{abstract}
Introduction: This study aimed to assess the postpartum women's level of comprehension of newborn care practices taught at a rooming-in facility.

Methods: In this cross-sectional study, a Likert scale was used to assess the participants' level of comprehension of the postpartum instructions provided by the nursing staff at a maternity ward of a teaching hospital in southern Brazil.
\end{abstract}

Results: A total of 196 women were interviewed. The analysis of the overall level of comprehension of newborn care instructions, assessed by means of Likert scale scores, was considered satisfactory, with a mean comprehension of $77.19 \%$ (SD: $17.3 \%$ ) and a median comprehension of $80 \%$ (IQR: 70-90).

Conclusions: The newborn care instructions provided by the nursing staff at a rooming-in facility were satisfactorily understood by the postpartum women.

Keywords: Rooming-in; newborn; postpartum period; nursing care

Rooming-in is defined as a hospital practice in which healthy newborns and their mothers stay together 24 hours a day, sharing the same room until hospital discharge. With this arrangement, all the necessary care is provided, as well as education to the mother related to her and her child's health ${ }^{1}$.

The basic principles of the rooming-in model are caring for the mother and the child, and instructing the mother on how to care for herself and her child $^{2}$. Health professionals play an essential role in this context of health promotion and should have specific knowledge and technical skills to develop their function ${ }^{3}$. The nursing staff should be available and interested in listening to and answering questions and concerns from the mother, having in mind that hospital stay is significant to prepare the mother to care for her child ${ }^{4}$. The educational role of the nursing staff transforms and expands the concept of health care itself - in the rooming-in model, the actions of caring and treating are not the sole responsibility of these professionals, involving the co-participation of the mother ${ }^{5}$. The mother who is able to care for her child and understand her child's comprehensive needs becomes a health promoter at individual, social, family, and ecological levels ${ }^{6}$.

The postpartum period is significant to the mother, the newborn, and the family because it involves the physiological adjustment of the mother and the child. It is also important to the emotional and social adjustments of all those involved ${ }^{7}$. The rooming-in facility is a favorable environment to prepare and instruct postpartum women on self-care and newborn care ${ }^{8}$.

The puerperium is considered a risky period; thus, the nursing staff should have the necessary skills to provide care based on prevention of complications and on the mother's physical and emotional comfort, as well as to perform educational actions that help the mother prepare for self-care and newborn care ${ }^{9}$. This team approach should include listening to the mother and acknowledging the specificities of female needs, which result from the social aspects of motherhood ${ }^{8}$.

http://seer.ufrgs.br/hcpa

(cc)BY

ISSN 2357-9730
Clin Biomed Res. 2017;37(3):193-197

1 Intensive Care Unit, Hospital Municipal de Novo Hamburgo, Fundação de Saúde de Novo Hamburgo. Novo Hamburgo, RS, Brazil.

2 Department of Maternal and Child Health, School of Nursing, Universidade Federal do Rio Grande do Sul (UFRGS) Porto Alegre, RS, Brazil.

Corresponding author: Bruna Cabrera Dauber brunadauber@fsnh.net.br Hospital Municipal de Novo Hamburgo Av. Pedro Adams Filho, 6520, Centro. 93310-003, Novo Hamburgo, RS, Brazil. 
The postpartum woman, with her specific emotional and social characteristics, has the essential role of caregiver of her newborn; therefore, postpartum instructions provided by the nursing staff should be assessed. Although the educational actions performed in the rooming-in model are based on scientific knowledge, there is still a gap in the literature in terms of assessment and feedback to the nursing staff regarding the education of postpartum women. Thus, this study aimed to assess the postpartum women's level of comprehension of newborn care practices taught by the nursing staff at a rooming-in facility.

\section{METHODS}

This was a quantitative cross-sectional study ${ }^{10}$. Data collection was performed at a rooming-in facility of an obstetric care unit of a teaching hospital in Porto Alegre, Rio Grande do Sul, Brazil, from February to April of 2016. The population consisted of postpartum women who were roomed-in with their newborns. Postpartum women with physical impairment, those aged less than 18 years, and those whose newborns showed complications during obstetric care unit stay were excluded.

The sample size was calculated using the WINPEPI software, version 11.43 , considering a prevalence of $50 \%$ of satisfactory comprehension, an error of $7 \%$, and a confidence level of $95 \%$. The estimated sample size was 196 postpartum women.

Participant selection involved consulting obstetric care unit records daily to identify postpartum women who had delivered within 36 to 48 hours. Then, inclusion and exclusion criteria were applied. Finally, the participants signed an informed consent form and were interviewed. Data collection was performed by the authors, who assessed the participants' answers using a Likert scale. Medical records were reviewed to complement the study instrument.

During obstetric care unit stay, postpartum women are instructed on newborn care. The nursing staff, which consists of nurses and practical nurses, is responsible for explaining and demonstrating how newborn care practices should be performed. According to the routine of this teaching hospital, the nurse is in charge of providing individual instructions and distributing illustrated brochures. The hospital adopts standard operating procedures that guide instructions and methods of newborn care.

The predictive variables of this study included 10 newborn care practices taught to postpartum women during obstetric care unit stay, as follows: bathing technique, bathing materials, temperature of bath water, risk of falls, use of appropriate newborn clothing, use of talcum powder, use of pacifier, hygienic umbilical stump care, back sleeping position (to prevent sudden infant death syndrome), and changing diapers. The outcome variables were the scores of a Likert scale, which measured the postpartum women's level of comprehension of each of the 10 instructions provided by the nursing staff. The postpartum woman was considered to have a satisfactory comprehension of a given practice when she scored 4 or 5 in the Likert scale, equivalent to very clear and totally clear comprehension respectively.

A Likert scale is used to measure attitudes, behaviors, and domains of quality of life related to health. The interviewees receive a list of questions and are requested to provide a score for each item, ranging from 1 to $5^{10}$. The highest (5) and the lowest (1) scores are equivalent to totally clear and totally unclear comprehension respectively ${ }^{11}$. In the present study, scores 2, 3, and 4 were considered unclear, clear, and very clear comprehension respectively. According to the literature on assessment using a Likert scale, scores 4 and 5 represent satisfactory comprehension ${ }^{10}$.

The assessment instrument was designed by the authors to provide feedback to the nursing staff on their educational performance at the rooming-in facility of a teaching hospital in southern Brazil. Although the instrument has not been validated yet, we intend to do so in order to make it available to professionals from other rooming-in facilities. The aim of this instrument is to assess aspects of the nursing staff's educational role in this context, which will help identify difficulties and achievements related to the instructions provided to postpartum women.

The postpartum women's profile was described using data obtained from the interviews and the medical records, including site of prenatal care, number of prenatal visits, profession, level of education, marital status, number of pregnancies and children, and modes of delivery. During the individual interview, the participants were requested to specify which aspects of each Likert scale item had been mentioned by the nursing staff. Regarding the back sleeping position, for instance, they were asked whether the reason for this position had been explained, as well as the risks and benefits to the newborn.

The statistical analysis of the postpartum women's level of comprehension of the instructions was performed through the sum of the number of items with a score 4 (very clear) or 5 (totally clear). Data were organized and processed using SPSS, version 18.0. Descriptive and analytical statistics were used for data analysis, and the significance level was set at $5 \%$. The association between categorical variables was assessed with the chi-square test, while the comparison of distributions of comprehension percentage 
scores across levels of education and modes of delivery was performed with the Kruskal-Wallis test. The correlation between number of prenatal visits and comprehension score was assessed using the Spearman's correlation coefficient.

Ethical aspects were in accordance with the Resolution number 466/2012 of the Brazilian National Health Council. The research project was approved by the Research Ethics Committee of our institution with protocol number 160048 .

\section{RESULTS}

A total of 196 postpartum women were interviewed. The prevalent age group was 23 to 27 years, with $62(31.7 \%)$ women. Regarding site of prenatal care, 125 women $(63.8 \%)$ received prenatal care at primary health care units, 39 (19.9\%) used private services, $28(14.3 \%)$ had high-risk pregnancy and received prenatal care at the teaching hospital, $2(1 \%)$ had high-risk pregnancy and received prenatal care at other hospitals, and $2(1 \%)$ did not receive any prenatal care. The median number of prenatal visits was 8 (interquartile range [IQR]: 7-10). Most women (111, or $56.6 \%)$ reported being single. Furthermore, $36.2 \%$ reported having high school degree and $40.3 \%$ were primiparas.

The statistical analysis of the overall level of comprehension of the 10 instructions with satisfactory scores showed a mean comprehension of $77.2 \%$ (standard deviation (SD): $17.3 \%$ ) and a median comprehension of $80 \%$ (IQR: $70-90$ ) (Figure 1).

The comparison between level of education and comprehension percentage score showed no significant difference $(p=0.324)$. Almost all women
$(97.4 \%)$ reported not having any questions on hygienic umbilical stump care. Conversely, $81.1 \%$ reported not having been instructed on the use of talcum powder (Table 1).

According to the research data, $124(63,3 \%)$ postpartum women had vaginal delivery and $72(36.7 \%)$ had cesarean delivery. Regarding the influence of this variable on the dynamics of newborn care, $81.5 \%$ of postpartum women who had vaginal delivery reported that the mode of delivery had a favorable influence on recovery and newborn care vs. $47.2 \%$ of postpartum women who had cesarean delivery. This difference was significant $(p=0.001)$. In addition, there was no correlation between number of prenatal visits and level of comprehension of postpartum instructions $(p=0.981)$.

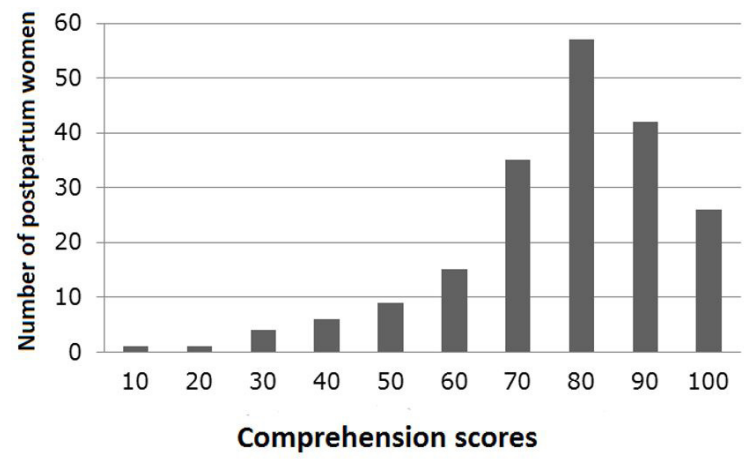

Figure 1: Postpartum women's comprehension percentage scores $(n=196)$. Porto Alegre, RS, Brazil, 2016. Source: Research data, 2016.

Table 1: Assessment of postpartum women's level of comprehension using a Likert scale. Porto Alegre, RS, Brazil, 2016.

\begin{tabular}{|c|c|c|c|c|c|c|}
\hline \multirow[b]{3}{*}{ Instruction } & \multicolumn{6}{|c|}{ Level of comprehension } \\
\hline & 1 & 2 & 3 & 4 & 5 & \\
\hline & $\begin{array}{c}\text { Totally } \\
\text { unclear } \\
\text { n (\%) }\end{array}$ & $\begin{array}{l}\text { Unclear } \\
\text { n (\%) }\end{array}$ & $\begin{array}{l}\text { Clear } \\
\text { n (\%) }\end{array}$ & $\begin{array}{c}\text { Very clear } \\
\text { n (\%) }\end{array}$ & $\begin{array}{c}\text { Totally clear } \\
\text { n (\%) }\end{array}$ & $\begin{array}{l}\text { Total } \\
\mathrm{n}(\%)\end{array}$ \\
\hline Humane bathing technique & $5(2.6 \%)$ & $2(1 \%)$ & $8(4.1 \%)$ & $10(5.1 \%)$ & $171(87.2 \%)$ & $196(100 \%)$ \\
\hline Bathing materials & $6(3.1 \%)$ & $1(0.5 \%)$ & $6(3 \%)$ & $10(5.1 \%)$ & $173(88.3 \%)$ & $196(100 \%)$ \\
\hline Temperature of bath water & $11(5.6 \%)$ & $7(3.6 \%)$ & $9(4.6 \%)$ & $8(4.1 \%)$ & $161(82.1 \%)$ & $196(100 \%)$ \\
\hline Risk of falls & $10(5.1 \%)$ & $4(2 \%)$ & $2(1 \%)$ & $5(2.6 \%)$ & $175(89.3 \%)$ & $196(100 \%)$ \\
\hline $\begin{array}{l}\text { Use of appropriate newborn } \\
\text { clothing }\end{array}$ & $47(24 \%)$ & $7(3.6 \%)$ & $10(5 \%)$ & $9(4.6 \%)$ & $123(62.8 \%)$ & $196(100 \%)$ \\
\hline Use of talcum powder & $159(81.1 \%)$ & $3(1.5 \%)$ & $1(0.6 \%)$ & $0(0 \%)$ & $33(16.8 \%)$ & $196(100 \%)$ \\
\hline Use of pacifier & $36(18.4 \%)$ & $19(9.7 \%)$ & $5(2.5 \%)$ & $1(0.5 \%)$ & $135(68.9 \%)$ & $196(100 \%)$ \\
\hline $\begin{array}{l}\text { Hygienic umbilical stump } \\
\text { care }\end{array}$ & $2(1 \%)$ & $1(0.5 \%)$ & $2(1.1 \%)$ & $0(0 \%)$ & $191(97.4 \%)$ & $196(100 \%)$ \\
\hline Back sleeping position & $50(25.5 \%)$ & $8(4.1 \%)$ & $5(2.6 \%)$ & $1(0.5 \%)$ & $132(67.3 \%)$ & $196(100 \%)$ \\
\hline Changing diapers & $11(5.6 \%)$ & $1(0.5 \%)$ & $8(4.1 \%)$ & $2(1 \%)$ & $174(88.8 \%)$ & $196(100 \%)$ \\
\hline
\end{tabular}

Source: Research data, 2016. 


\section{DISCUSSION}

The level of comprehension of postpartum instructions was measured using a Likert scale applied to mothers roomed-in with their newborns at a teaching hospital in Porto Alegre, southern Brazil. Their comprehension was satisfactory, since there was a median of $80 \%$ of comprehension. This finding shows that the postpartum instructions provided by the nursing staff were effective and postpartum women were able to understand newborn care practices appropriately. Providing clear instructions are essential because without them some practices may be performed inappropriately, causing harm to the newborn and increasing emergency visits due to lack of training and knowledge. In the postpartum period, women who received early discharge, women who did not receive prenatal care, and single women are the ones who seek emergency rooms more often ${ }^{12}$.

In the present study, $83.1 \%$ of postpartum women received prenatal care $-63.8 \%$ at primary health care units and $19 \%$ at private services, which was similar to the proportion of private prenatal care found in a study conducted in the state of Piauí, northeastern Brazil. This study was also performed at a public hospital, where 50 primiparous women were interviewed in order to assess their difficulties in newborn care ${ }^{13}$.

The comprehension of postpartum instructions was not significantly associated with the number of prenatal visits. Additionally, the level of education was not a significant factor for understanding the instructions. In the present study, most women completed high school, followed by middle school, and a minority had complete or incomplete higher education, which was similar to the findings of the study conducted in Piauí ${ }^{13}$.

Regarding hygienic umbilical stump care, our study showed that postpartum women understood how to perform the technique and had no questions. Thus, they were feeling prepared and ready to perform it. However, another study has shown that postpartum women are afraid of cleaning their newborn's umbilical stump because they erroneously believe that the newborn will feel pain or are unfamiliar with the appropriate technique ${ }^{14}$.

A study assessing maternal knowledge of the newborn's sleeping position has revealed that only $20 \%$ of postpartum women at a maternity ward in the state of Rio Grande do Sul reported knowing how to position their newborns appropriately ${ }^{15}$. In the present study, $67.3 \%$ of postpartum women reported having learned the appropriate position, which is extremely important to prevent sudden death and should be well explained by the nursing staff.

According to the study conducted in Piauí, $46 \%$ of parents had questions on how to dress their newborns ${ }^{13}$. In the present study, the instruction on the use of appropriate newborn clothing was satisfactorily understood by $67.4 \%$ of postpartum women. Conversely, the instruction on the use of talcum powder was poorly understood by $81.1 \%$ of women, which shows the need to emphasize this lesson. A study performed in Rio de Janeiro has found that a course on newborn care increased the number of parents who would not use talcum powder from $74.1 \%$ to $89.3 \%^{16}$.

Among the newborn care practices performed by parents, the bathing technique has been described as their greatest difficulty ${ }^{13}$. The present study found a satisfactory result for this instruction, with a level of comprehension of $92.3 \%$. The instruction on how to change diapers was satisfactorily understood by $176(89.8 \%)$ women, which is consistent with a study conducted in the United Kingdom that has found a high rate $(95.6 \%)$ of comprehension of this lesson ${ }^{17}$. Therefore, this technique seems to be easily learned.

A limitation of the present study was the lack of previous studies on the same topic. Another limiting factor was the impossibility of cross-checking the instructions performed by the nursing staff and the answers provided by the participants, since the nursing staff was not observed during the instruction period.

\section{CONCLUSIONS}

In the present study, the level of comprehension of newborn care instructions was assessed in postpartum women admitted to a rooming-in facility at a teaching hospital. According to the results, the instructions provided by the nursing staff were satisfactorily understood by the postpartum woman, which means that these professionals are performing their educational role effectively.

The nursing staff create bonds with families by helping and preparing new mothers and their families to provide appropriate care to their newborns. The rooming-in facility is a proper environment to share knowledge. Because postpartum women are in a different emotional moment, undergoing a process of family transition, the nursing staff should be able to understand and guide them, answering questions and helping with newborn care.

Future studies are required to assess the postpartum women's level of comprehension of instructions provided by the nursing staff and to identify their major difficulties, which is an educational challenge to the staff. The assessment instrument based on a Likert scale developed in the present study could be used before hospital discharge in order to help the nursing staff evaluate the postpartum women's comprehension of newborn care practices. This may result in a more appropriate learning before discharge.

\section{Conflicts of interest}

The authors declare no conflicts of interest. 


\section{REFERENCES}

1. Soares AV, Gaidzinski RR, Cirico MO. Identificação das intervenções de enfermagem no Sistema de Alojamento Conjunto. Rev Esc Enferm USP. 2010;44(2):30817. PMid:20642040. http:// dx.doi.org/10.1590/S008062342010000200010 .

2. Crenshaw JT. Healthy birth practice \#6: keep mother and baby together- it's best for mother, baby, and breastfeeding. Perinat Educ. 2014;23(4):211-7. PMid:25411542. http://dx.doi.org/10.1891/10581243.23.4.211.

3. Figueiredo MS, Silva RA, Oliveira DK, Vieira NR, Costa DA, Davim RM. Grau de satisfação de puérperas quanto à qualidade da assistência no alojamento conjunto de uma maternidade pública. Rev Pesqui Cuid Fundam. 2015;7:2697-706. http:// dx.doi.org/10.9789/2175-5361.2015. v7i3.2697-2706.

4. Ciaramella J, Longworth N, Larraz L, Murphy S. Improving efficiency, consistency and satisfaction on a mother-baby unit with the discharge nurse position. Nurs Womens Health. 2014;18(4):333-9. PMid:25145721. http://dx.doi.org/10.1111/1751486X.12138.

5. Costa NS, Pereira BD, FonsecaMachado MO, de Mattos JG, Elias TC, da Silva SR. Cuidados com recémnascido realizados por puérperas em um alojamento conjunto. Cienc Cuid Saude. 2013;12:633-9.

6. Fonseca LM, Scochi CG, de Mello DF. Educação em Saúde de puérperas em alojamento conjunto neonatal: aquisição de conhecimento mediado pelo uso de um jogo educativo. Rev Lat Am Enfermagem. 2002;10(2):166-71. PMid:12138560. http://dx.doi.org/10.1590/S010411692002000200007.

7. Mendonça FA, Nations MK, Sampaio LR, Coutinho GG, de Menezes GB, do Nascimento JC, et al. Cuidados prestados pelo pai ao recém-nascido no alojamento conjunto do Hospital Gonzaguinha de Messejana. CIAIQ2016. 2016;2:1570-8.

8. Almeida MS, Silva IA. Necessidades de mulheres no puerpério imediato em uma maternidade pública de Salvador, Bahia, Brasil. Rev Esc Enferm USP. 2008;42(2):347-54. PMid:18642748. http://dx.doi.org/10.1590/S008062342008000200019 .

9. Lai $\mathrm{YL}$, Hung $\mathrm{CH}$, Stocker J, Chan TF, Liu Y. Postpartum fatigue, baby-care activities, and maternalinfant attachment of vaginal and cesarean births following rooming-in. Appl Nurs Res. 2015;28(2):11620. PMid:25468429. http://dx.doi. org/10.1016/j.apnr.2014.08.002.

10. Hulley SB, Cummings SR, Browner WS, Grady DG, Newman TB. Delineando a pesquisa clínica: uma abordagem epidemiológica. Porto Alegre (RS): Artmed; 2008.

11. Lobiondo-Wood G, Haber J. Pesquisa em enfermagem: métodos, avaliação crítica e utilização. 4 ed. Rio de Janeiro (RJ): Guanabara Koogan; 2001.

12. Lee HC, Bardach NS, Maselli JH, Gonzales R. Emergency department visits in the neonatal period in the
United States. Pediatr Emerg Care. 2014;30(5):315-8. PMid:24759490. http://dx.doi.org/10.1097/ PEC. 0000000000000120 .

13. Lopes KD, Oliveira JG No, Sá GG, Carvalho DA, Monteiro MM, Carvalho e Martins MC. Dificuldades nos cuidados ao recém-nascido: realidades de puérperas primíparas. Rev Saude Publica. 2015;8:19-33.

14. Carvalhêdo DS, Lotufo FM, Barbosa MA, Gaíva MA. As vivências e os significados do primeiro banho dado pela puérpera em seu filho recém-nascido. Rev Enferm Global. 2010;19:1-15.

15. Cesar JA, Cunha CF, Sutil AT, Santos GB. Opinião das mães sobre a posição do bebê dormir após campanha nacional: estudo de base populacional no extremo sul do Brasil. Rev Bras Saude Mater Infant. 2013;13(4):329-33. http://dx.doi.org/10.1590/S151938292013000400005.

16. Gomes AL, Rocha CR, Henrique DM, Santos MA, Silva LR. Conhecimentos de familiares sobre os cuidados com recém-nascidos. Rev Rene. 2015;16:258-65. http://dx.doi.org/10.15253/21756783.2015000200016 .

17. Furber C, Bedwell C, Campbell M, Cork M, Jones C, Rowland L, et al. The challenges and realties of diaper area cleansing for parents. Obstet Gynecol Neonatal Nurs. 2012;41(6):E13-25. PMid:22822929. http://dx.doi.org/10.1111/j.15526909.2012.01390.x. 